\title{
Desafios do novo Qualis para a pós-graduação e o periodismo científico brasileiros
}

\section{Challenges of the new Qualis to the Brazilian post-graduation and scientific periodism}

Finalmente o novo Qualis da Capes foi disponibilizado oficialmente e os desdobramentos desta definição, que aliás já vem ocorrendo, provavelmente ainda se farão sentir mais fortemente dadas as suas conseqüências mediatas ou imediatas para as pós-graduações e para as Revistas produzidas no Brasil. De fato vários programas de pós-graduação e pesquisadores individualmente têm-se pronunciado a respeito.

Em Editorial anterior desta Revista tecíamos alguns comentários sobre o assunto no tocante à publicação de artigos nas Revistas nacionais, e como alguns cursos corriam o risco de não sobreviver. Mas concluíamos com esperança:

"Não é razoável publicar e perecer!.

Como comunidade científica, no presente contexto, cabe, portanto respondermos ponderadamente e de maneira certa, ao presente desafio."

Entretanto antes de ser colocada a questão de como consegui-lo, é natural que busquemos descortinar o panorama com que nos deparamos frente aos novos critérios do Qualis.

Pelo menos três elementos nesse cenário são, de imediato, visíveis, sendo que os dois primeiros, citados a seguir, têm sido objeto de questionamentos:

O primeiro é a provável redução do número de submissões de manuscritos às Revistas, o que poderá ocorrer não só para as revistas brasileiras melhor ranqueadas no SciELO e mesmo como fator de impacto no ISI, como também e, particularmente, para as Revistas classificadas em mais baixos índices de avaliação. E naturalmente isto conduzirá a um empobreciemnto qualitativo e talvez à extinção daquelas mais frágeis.

Em segundo lugar, como também já levantado por outros, vários programas de pós-graduação, serão também atingidos, passando a serem classificados na CAPES com conceito mais baixos que os atuais. É claro que aqueles programas atualmente em nível 6 e 7 têm muito fôlego ainda e suporte para se manterem como tais ou com pequena redução no ranking. Assim as implicações negativas para estes não serão muito significativas. Todavia a maioria das pós-graduações no Brasil, que estão classificados nos conceitos 4 e 5 sofrerão mais. É uma grande massa de programas atingidos, embora tudo indique que de algum modo suportarão as consequências. Por fim, é de esperar o possível aniquilamento daqueles programas hoje classificados com conceito 3, que estão certamente lutando para crescer mas, ao contrário, fatalmente serão rebaixados a nível de quase desaparecimento. Muitos destes programas poderão se perceber em uma situação até sem retorno. Em suma, estes últimos, tendo sido incluídos como cursos com perspectiva de crescimento, poderão sofrer, na pele, o impacto daquela frase terrível, escrita na porta do inferno: "Deixai toda a esperança vós que entrais" (Divina Comédia).

Em terceiro lugar verifica-se que a proposição do novo Qualis já tem sido criticada de vários ângulos. Ademais é muito provável que haverá no Brasil um incremento do número de estudos - o que aliás já vem sendo empreendido há tempos na área de bibliometria - com o objetivo de esclarecer o que significa e qual a representatividade do Fator de Impacto como indicador da qualidade de uma revista científica.

De uma melhor compreensão desses problemas e do seu enfrentamento poderão surgir as respostas à nossa questão: "Como enfrentar o desafio"?

José Eulálio Cabral Filho

Editor Executivo da Revista Brasileira de Saúde Materno Infantil 